Alexander, Victoria D. (1996). Museums and Money: The Impact of Funding on Exhibitions, Scholarship, and Management. Bloomington, IN: Indiana University Press.

ISBN-10: 0253332052; ISBN-13: 9780253332059 . Length: xiii + 167 pages.

Reviewed in American Journal of Sociology, Administrative Science Quarterly, and Contemporary Sociology.

From the Inside Cover:

Recent controversies over politically sensitive or allegedly pornographic museum exhibitions have called attention to the sources of funding, public and private, of museums and other cultural organizations. Should funders have a say in what gets exhibited by a museum? Would this constitute censorship or merely be a reasonable restraint over the way public or corporate funds are used? While funding for the arts was shifting from individuals to institutions, including the federal government, did the mission and management of museums change?

Museums \& Money looks at thirty large art museums and how they have been affected by the changing patterns of funding for the arts in America over the past thirty-five years. Full of insights into the world of arts organizations, Victoria Alexander's study raises important cultural questions as well, with far-reaching implications for the way art is defined, produced, and presented in contemporary America.

\section{Thuseums \&}
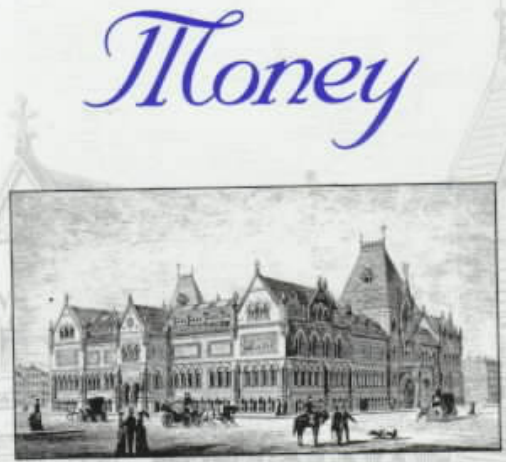

THE IMPACT

OF FunDING

on ExhIBITIONS,

SCHOLARSHIP,

AND MANAGEMENT

Victoria D. Alexander 